\title{
Optimasi K-Means Clustering Menggunakan Particle Swarm Optimization pada Sistem Identifikasi Tumbuhan Obat Berbasis Citra
}

\author{
K-Means Clustering Optimization Using Particle Swarm \\ Optimization on Image Based Medicinal Plant Identification System
}

FRANKI YUSUF BISILISIN ${ }^{1}$, YENI HERDIYENI ${ }^{1 *}$, BIB PARUHUM SILALAHI ${ }^{2}$

\begin{abstract}
Abstrak
Teknologi identifikasi pada penelitian ini diperlukan untuk mempercepat proses identifikasi spesies tumbuhan obat berupa data citra digital. Penelitian ini membangun sistem identifikasi tumbuhan obat menggunakan teknik clustering. Teknik clustering digunakan untuk mengelompokkan data citra sesuai dengan spesies tumbuhan obat. Penelitian ini bertujuan melakukan optimasi k-means clustering menggunakan metode particle swarm optimization (PSO). Metode PSO digunakan untuk mengatasi kelemahan pada metode clustering tradisional yaitu pemilihan pusat cluster awal dan solusi lokal. Proses ekstraksi fitur menggunakan fuzzy local binary pattern (FLBP) untuk merepresentasikan tekstur dari citra. Implementasi program menggunakan bahasa pemrograman $\mathrm{C}++$. Analisis clustering dilakukan untuk 30 spesies tumbuhan obat yang ada di Indonesia dengan jumlah 48 citra masing-masing spesies. Pengukuran kualitas clustering menggunakan nilai quantization error dan akurasi. Hasil yang diperoleh menunjukkan metode PSO mampu meningkatkan kinerja dari metode $k$-means clustering dalam proses identifikasi tumbuhan obat.
\end{abstract}

Kata kunci: fuzzy local binary pattern, $k$-means clustering, particle swarm optimization, tumbuhan obat

\begin{abstract}
Automatic identification technology is required to accelerate the process of identification of medicinal plant species in the form of digital image data. This research used clustering techniques to build the system identification of medicinal plants. Clustering technique was used to classify the image data according to the species of medicinal plants. The purpose of this study was to optimize the k-means clustering using particle swarm optimization (PSO). PSO method was used to overcome the shortcomings of traditional clustering algorithms such as the selection of the initial cluster centers and local solutions. The feature extraction was conducted by using fuzzy local binary pattern (FLBP) to represent the texture of the image. The program was implemented in $C++$ programming language. Clustering analysis was performed for 30 species of Indonesian medicinal plants with 48 images of each species. The values of quantization error and accuracy were utilized to measure the quality of clustering. Clustering results showed that PSO was able to improve the performance of $k$ means clustering in the identification process of medicinal plants.
\end{abstract}

Keywords: fuzzy local binary pattern, $k$-means clustering, medicinal plant, particle swarm optimization

\section{PENDAHULUAN}

Indonesia merupakan negara dengan tingkat keanekaragaman hayati yang tinggi. Groombridge dan Jenkins (2002) mencatat bahwa terdapat 22500 spesies tumbuhan obat di Indonesia. Jumlah spesies yang telah dimanfaatkan sebagai tumbuhan obat sebanyak 1000

\footnotetext{
${ }^{1}$ Departemen Ilmu Komputer, Fakultas Matematika dan Ilmu Pengetahuan Alam, Institut Pertanian Bogor, Bogor 16680

${ }^{2}$ Departemen Matematika, Fakultas Matematika dan Ilmu Pengetahuan Alam, Institut Pertanian Bogor, Bogor 16680

*Penulis korespondensi: Tel/Faks: 0251-8625584; Surel: yeni_herdiyeni@ipb.ac.id
} 
spesies. Hal ini menunjukkan bahwa jumlah persentase tumbuhan obat yang telah dimanfaatkan hanya sebesar $4.4 \%$ dari sumber daya tumbuhan obat yang tersedia. Salah satu penyebab kurangnya pemanfaatan tumbuhan obat adalah minimnya pengetahuan masyarakat mengenai potensi tumbuhan obat. Peningkatan pengetahuan masyarakat tentang tumbuhan obat dapat dibantu dengan dikembangkannya sistem identifikasi tumbuhan obat.

Teknologi identifikasi secara otomatis diperlukan untuk mempercepat proses identifikasi dengan menggunakan organ vegetatif seperti daun. Sistem identifikasi terdiri atas dua teknik, yaitu teknik klasifikasi dan teknik clustering. Adapun penelitian menggunakan teknik klasifikasi yang sudah dilakukan, salah satunya pada penelitian Herdiyeni dan Wahyuni (2012) yang menggunakan metode ekstraksi fitur fuzzy local binary pattern (FLBP) dan metode klasifikasi probabilistic neural network (PNN) untuk identifikasi tumbuhan obat. Dengan menggunakan teknik klasifikasi banyak data tumbuhan obat yang belum teridentifikasi sehingga teknik unsupervised learning, yakni clustering, diusulkan untuk membandingkan hasil identifikasi tumbuhan obat dengan teknik klasifikasi.

Menurut Jain et al. (1999), clustering adalah ilmu yang mempelajari hubungan antara satu data dan data yang lain kemudian mengelompokkannya menjadi satu kategori tertentu. Metode clustering yang paling banyak digunakan ialah metode $k$-means clustering. Kelemahan utama dari metode ini adalah hasil yang sensitif terhadap pemilihan pusat cluster awal dan perhitungan solusi lokal untuk mencapai kondisi optimal. Menurut Panchal et al. (2009), pemilihan pusat cluster awal dan perhitungan solusi lokal mempengaruhi proses dari kinerja metode dan hasil partisi data. Kelemahan pemilihan pusat cluster awal dan perhitungan solusi lokal pada metode k-means clustering memberikan motivasi untuk menerapkan metode particle swarm optimization (PSO). Menurut Panchal et al. (2009), PSO dapat digunakan untuk menemukan pusat cluster baru sesuai dengan jumlah cluster yang sudah ditentukan. Algoritme dimodifikasi menggunakan metode k-means clustering untuk pengelompokan awal, kemudian PSO memperbaiki kelompok data yang dibentuk oleh $k$ means clustering. Nilai quantization error dan akurasi digunakan untuk mengukur seberapa baik metode PSO yang diterapkan.

Penelitian ini bertujuan melakukan optimasi $k$-means clustering menggunakan metode PSO untuk meningkatkan hasil identifikasi tumbuhan obat.

\section{METODE}

Penelitian ini menggunakan pendekatan secara sistem. Ekstraksi fitur pada citra menggunakan fuzzy local binary pattern (FLBP). Hasil ekstraksi berupa ciri dari citra akan dikelompokkan menggunakan k-means clustering dan PSO based k-means clustering untuk identifikasi citra. Metode penelitian yang akan dilakukan seperti ditunjukkan pada Gambar 1 .

\section{Data Citra Tumbuhan Obat}

Proses pengambilan citra daun tumbuhan obat dilakukan dengan pemotretan tiga puluh jenis tumbuhan obat di kebun Biofarmaka IPB dan di rumah kaca Pusat Konservasi Ex-Situ Tumbuhan Obat Hutan Tropika Indonesia, Fahutan, IPB. Pemotretan dilakukan dengan menggunakan lima kamera digital yang berbeda (DSC-W55, 7210 Supernova, Canon Digital Axus 95 IS, Samsung PL100, dan EX-Z35). Total citra daun tumbuhan obat yang digunakan adalah 1440 yang terdiri atas 30 spesies dengan masing-masing spesies terdiri atas 48 citra. 


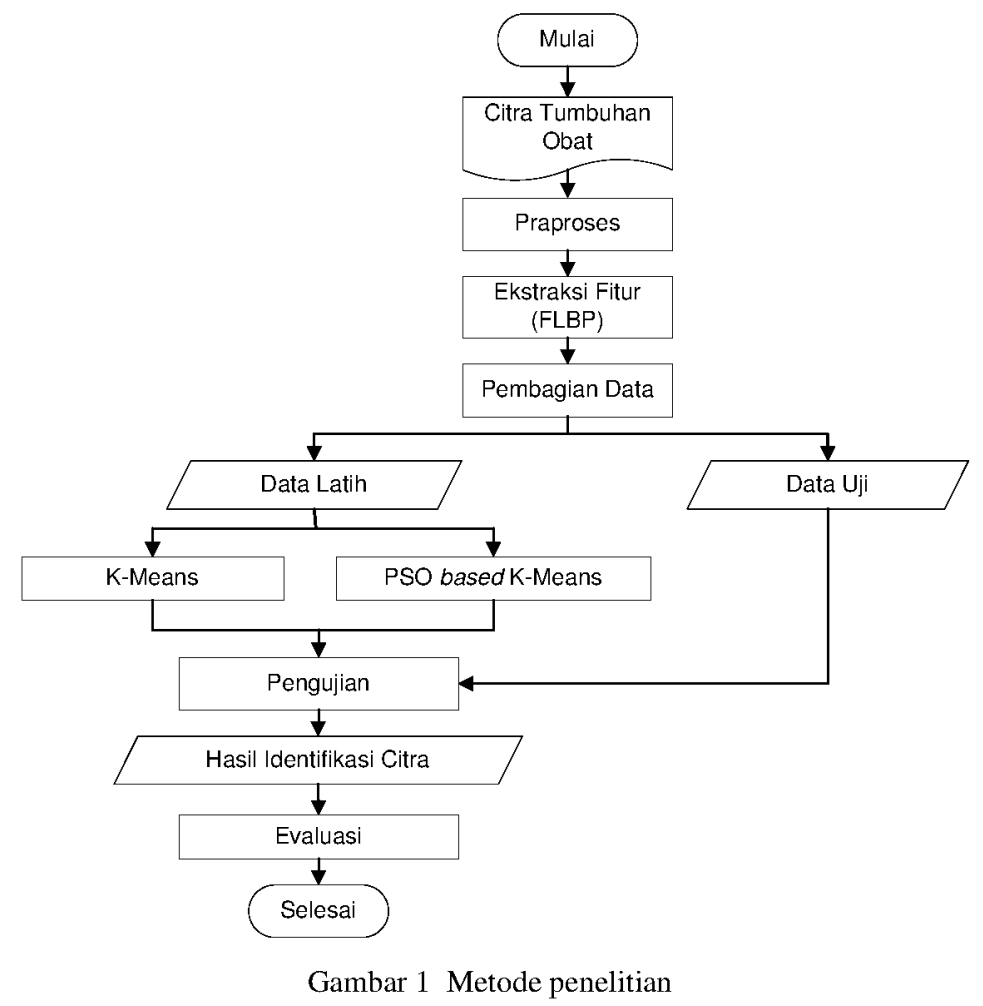

\section{Praproses}

Praproses adalah tahap awal dari proses identifikasi tumbuhan obat. Proses yang dilakukan pada tahap ini adalah mengganti latar belakang citra daun dengan warna putih. Ukuran citra diperkecil menjadi $270 \times 240$ piksel. Mode warna citra diubah menjadi grayscale sebagai input untuk proses ekstraksi fitur.

\section{Ekstraksi Fitur dengan Fuzzy Local Binary Pattern}

Menurut Iakovidis et al. (2008) proses local binary pattern (LBP) merepresentasikan tekstur lokal di sekitar tekstur pusat berdasarkan operator ketetanggaan LBP. Setiap pola tekstur LBP direpresentasikan oleh sembilan elemen $P=\left\{P_{\text {center }}, P_{0}, P_{1}, \ldots, P_{7}\right\}, P_{\text {center }}$ merupakan nilai piksel pusat dan $P_{i}(0 \leq i \leq 7)$ merupakan nilai piksel sekelilingnya (circular sampling). Nilai circular sampling dapat dicirikan oleh nilai biner $d_{i}(0 \leq i \leq 7)$ yang kemudian akan dikonversi ke nilai desimal untuk mendapatkan nilai LBP dengan menggunakan Persamaan 1.

$$
L B P=\sum_{i=0}^{7} d_{i} \cdot 2^{i} \quad, L B P \quad \in[0,255]
$$

Nilai biner yang dihasilkan kemudian akan dikonversi ke nilai desimal untuk mendapatkan nilai LBP. Nilai-nilai LBP yang dihasilkan akan direpresentasikan melalui histogram. Menurut Ahonen et al. (2004) operator LBP dapat dikembangkan dengan menggunakan berbagai ukuran sampling points dan radius. Pengamatan piksel ketetanggaan, akan digunakan notasi $(P, R)$ dimana $P$ merupakan sampling points dan $R$ merupakan radius. Nilai LBP dihasilkan sesuai dengan operator LBP yang digunakan. Semakin kecil radius dan semakin besar sampling points yang digunakan, semakin banyak piksel yang diolah untuk mendapatkan nilai LBP.

Fuzzification pada proses LBP adalah transformasi variabel input menjadi variabel fuzzy berdasarkan pada sekumpulan fuzzy rule. Berdasarkan penelitian Iakovidis et al. (2008), 
penelitian ini menggunakan dua fuzzy rule untuk menentukan representasi nilai biner dan mencari nilai fuzzy. Kedua rule ialah:

Rule $R_{0}$ : semakin negatif nilai $\Delta P_{i}$, maka nilai kepastian terbesar dari $d_{i}$ adalah 0 .

Rule $R_{1}$ : semakin positif nilai $\Delta P_{i}$, maka nilai kepastian terbesar dari $d_{i}$ adalah 1 .

Rule $R_{0}$ dan $R_{1}$ merepresentasikan threshold $(F)$ FLBP yang mengontrol derajat ketidakpastian. Semakin besar nilai threshold yang digunakan, semakin banyak nilai piksel yang diolah dalam rentang fuzzy. Penggunaan threshold yang besar mempengaruhi waktu komputasi pada saat proses ektraksi fitur.

Metode LBP hanya menghasilkan satu kode LBP saja, sedangkan dengan metode FLBP menghasilkan satu atau lebih kode LBP. Nilai-nilai LBP yang dihasilkan FLBP memiliki tingkat kontribusi $\mathrm{C}_{L B P}$ yang berbeda, bergantung pada nilai-nilai fungsi keanggotaan yang dihasilkan. Ilustrasi dari proses FLBP seperti ditunjukkan pada Gambar 2. Pada penelitian ini, operasi LBP dengan FLBP menggunakan operator (8.2) dengan ukuran piksel $5 \times 5$ dan nilai threshold yang digunakan adalah $F=4$.

\section{Pembagian Data Latih dan Data Uji}

Pada tahap ini jumlah vektor data citra daun tumbuhan obat dibagi dengan komposisi data latih sebesar $80 \%$ dan data uji sebesar $20 \%$.

\section{K-Means Clustering}

Algoritme $k$-means clustering adalah algoritme untuk mengklasifikasikan atau mengelompokkan data berdasarkan atribut-atribut atau fitur-fitur ke dalam beberapa jumlah kelompok $\left(N_{c}\right)$ secara tepat, dimana $N_{c}$ adalah pusat cluster. Algoritme ini dimulai dengan menentukan pusat cluster awal secara acak. Setelah itu, objek data dalam dataset dikelompokkan ke pusat cluster berdasarkan jarak antara objek data dan pusat cluster. Algoritme k-means clustering (MacQueen 1967) terdiri dari pendefinisian pusat cluster awal, dan pengulangan dua langkah berikut ini:

(a) Pengelompokkan data ke dalam cluster

Pada langkah ini, data dimasukkan ke dalam salah satu cluster yang mempunyai pusat cluster terdekat dengan data tersebut. Dalam menghitung jarak antara data ke pusat cluster digunakan rumus Euclidean, didefinisikan pada Persamaan 2.

$$
d\left(z_{p}, m_{j}\right)=\sqrt{\sum_{k=1}^{N_{p}}\left(z_{p k}-m_{j k}\right)^{2}}
$$

dengan $N_{p}$ menunjukkan jumlah piksel citra, $z_{p}$ menunjukkan komponen $N_{p}$ piksel $p$, $m_{j}$ menunjukkan rata-rata pusat cluster $j$.

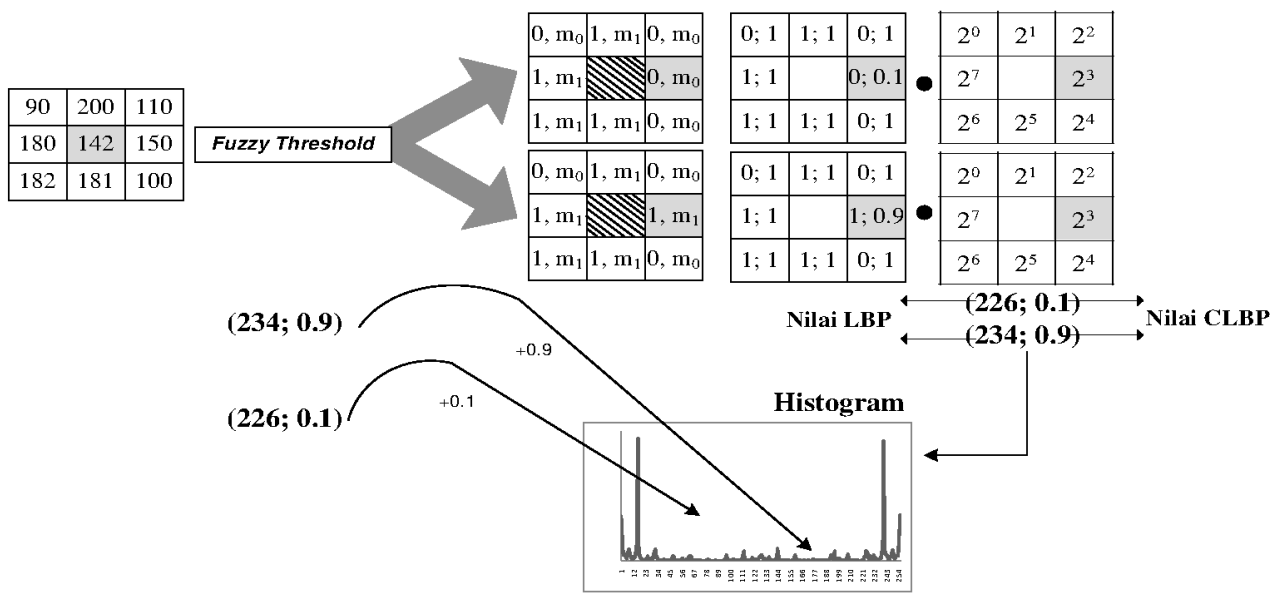

Gambar 2 Skema perhitungan FLBP dengan $F=10$ 
(b) Mencari pusat cluster yang baru

$$
m_{j}=\frac{1}{n_{j}} \sum_{\forall z_{p} \in C_{i j}} z_{p}
$$

$n_{j}$ adalah jumlah data yang dimiliki cluster $j$. Keanggotaan data $\left(C_{i j}\right)$ yang masuk ke cluster akan dihitung untuk mendapatkan pusat cluster baru.

\section{Particle Swarm Optimization}

Algoritme particle swarm optimization (PSO) diperkenalkan oleh Kennedy dan Eberhart (1995). Algoritme ini diinspirasi oleh perilaku sosial dari binatang seperti sekumpulan burung dalam suatu kumpulan (swarm). Perilaku sosial terdiri atas tindakan individu dan pengaruh dari individu-individu lain dalam satu kelompok. Setiap partikel di dalam PSO juga berhubungan dengan suatu kecepatan (velocity). Partikel-partikel mempunyai kecenderungan untuk bergerak ke area penelusuran yang lebih baik setelah melewati proses penelusuran.

Pada algoritme PSO, vektor kecepatan diperbaharui untuk masing-masing partikel, kemudian menjumlahkan vektor kecepatan tersebut ke posisi partikel. Proses memperbaharui kecepatan dipengaruhi oleh kedua solusi, yaitu melakukan penyesuaian posisi terbaik dari partikel (particle best) dan penyesuaian terhadap partikel terbaik dari seluruh kawanan ( global best). Pada tiap iterasi, setiap solusi yang direpresentasikan oleh posisi partikel dievaluasi dengan cara memasukkan solusi tersebut dalam fitness function (Santosa dan Willy 2011). Prosedur algoritme PSO ialah: (1) Inisialisasi populasi dari partikel-partikel dengan posisi dan kecepatan secara acak; (2) Evaluasi nilai fitness untuk masing-masing partikel; (3) Pembandingan dan pembaharuan particle best dan global best untuk tiap-tiap partikel berdasarkan fungsi fitness. Tahap selanjutnya adalah pengulangan langkah berikut sampai stopping criteria terpenuhi:

a Menggunakan particle best dan global best yang ada, perbaharui kecepatan setiap partikel. Dari kecepatan yang diperoleh, perbaharui posisi partikel dengan menjumlahkan kecepatan baru dan posisi sebelumnya menggunakan Persamaan 4 dan Persamaan 5.

$$
\begin{aligned}
& v_{i}(t)=w v_{i}(t-1)+c_{i} r_{i}\left(x_{p i}-x_{i}\right)+c_{2} r_{2}\left(x_{g i}-x_{i}\right) \\
& x_{i}(t)=x_{i}(t-1)+v_{i}(t)
\end{aligned}
$$

dengan

$i=$ indeks partikel

$t=$ iterasi

$w=$ inertia

$v_{i}=$ kecepatan partikel ke- $i$

$x_{i}=$ posisi partikel ke- $i$

$x_{g i}=$ posisi terbaik dari semua partikel (gbest)

$x_{p i}=$ posisi terbaik dari partikel ke- $i$ (pbest)

$c_{1,2}=$ learning rate

$r_{1,2}=$ bilangan acak $[0,1]$

b Evaluasi fitness dari setiap partikel

c Bandingkan dan perbaharui particle best dan global best tiap-tiap partikel berdasarkan fungsi fitness

d Cek stopping criteria. Jika terpenuhi, berhenti. Jika tidak, kembali ke (a) 


\section{PSO based $k$-means clustering}

Algoritme PSO based $k$-means clustering merupakan gabungan dari algoritme $k$ means clustering dengan algoritme PSO. Pengelompokkan data menggunakan algoritme PSO based $k$-means clustering menunjukkan hasil yang lebih baik dari metode $k$-means clustering (Van der Merwe dan Engelbrecht 2003). Di dalam konteks clustering, satu partikel merepresentasikan satu titik data pusat cluster. Setiap partikel $x_{i}=\left(m_{i 1}, \ldots, m_{i j}, \ldots, m_{i N_{c}}\right)$ dengan $m_{i j}$ mengacu pada $j$-th vektor pusat cluster dari partikel ke-i. Input dalam algoritme PSO based $k$ means clustering adalah populasi data yang akan dikelompokkan, jumlah cluster $\left(N_{c}\right)$ dan jumlah iterasi yang diinginkan. Prosedur pertama dalam algoritme PSO based k-means clustering adalah inisialisasi yang meliputi inisialisasi jumlah cluster, populasi data, iterasi maksimum, serta pendefinisian pusat cluster awal. Kemudian, jarak antara objek data dan pusat cluster (Euclidean distance) dihitung, lalu data dikelompokkan ke dalam cluster. Untuk menghitung nilai fitness, kualitas dari setiap partikel diukur menggunakan Persamaan 6

$$
f\left(x_{i}, Z\right)=\omega_{1} \bar{d}_{\max }\left(Z, x_{i}\right)+\omega_{2}\left(z_{\max }-d_{\min }\left(x_{i}\right)\right)
$$

dengan $z_{\max }$ adalah nilai maksimum piksel dalam set citra $\left(z_{\max }=2^{s}-1\right.$ untuk s-bit citra); $\mathbf{Z}$ adalah matriks yang mewakili pengolahan piksel citra ke cluster partikel $I$ di mana setiap elemen $z_{i j p}$ menunjukkan jika piksel $z_{p}$ adalah milik cluster $C_{i j}$ partikel I; nilai $\omega_{1}$ dan $\omega_{2}$ ditentukan oleh user;

$$
\bar{d}_{\max }\left(Z, x_{i}\right)=\max _{j=1, \ldots N_{c}}\left\{\sum_{\forall z_{p} \in C_{i j}} d\left(z_{p}, m_{j}\right) /\left|C_{i j}\right|\right\}
$$

adalah nilai rata-rata maksimum jarak Euclidean dari partikel untuk masing-masing kelas partikel dan

$$
d_{\min }\left(x_{i}\right)=\min _{\forall j 1, j 2, j 1 \neq j 2}\left\{d\left(m_{i i_{1}}, m_{i j_{2}}\right\}\right.
$$

adalah jarak Euclidean minimum antara setiap pasang cluster.

Fungsi fitness tersebut memiliki tujuan untuk meminimalkan intra-distance, yaitu jarak antara data dengan masing-masing pusat cluster, seperti yang diukur dengan $\bar{d}_{\max }\left(\boldsymbol{Z}, x_{i}\right)$, dan memaksimalkan inter-distance, yaitu jarak antara setiap pusat cluster, seperti yang diukur dengan $d_{\min }\left(x_{i}\right)$.

Dalam algoritme PSO based k-means clustering, yang digunakan adalah standar gbest PSO. Data dikelompokkan dengan dua langkah, yaitu (1) inisialisasi setiap partikel $(k)$ secara acak, (2) untuk $t=1$ sampai $t_{\max }$ lakukan langkah berikut:

(a) Untuk setiap partikel $i$ lakukan langkah berikut:

(b). Untuk setiap data vektor $z_{p}$

(i). Hitung jarak Euclidean $d\left(\boldsymbol{z}_{p}, \boldsymbol{m}_{j}\right)$ untuk semua pusat cluster $\mathrm{C}_{i j}$

(ii). Tentukan $(\mathrm{x}, \mathrm{y})$ ke cluster $\mathrm{C}_{i j}$ sehingga $d(x, y)=$ minimum

(iii). Hitung nilai fitness menggunakan persamaan (6)

(b) Perbaharui pbest dan gbest

(c) Perbaharui pusat cluster menggunakan persamaan (4) dan (5).

Kembali ke langkah 2 sampai kriteria terpenuhi, proses berhenti ketika tidak ada data yang berpindah cluster atau sampai jumlah maksimum iterasi yang ditantukan.

\section{Pengujian}

Pengujian untuk model $k$-means clustering dan PSO based $k$-means clustering dilakukan dengan menggunakan metode pengukuran jarak Euclidean, menggunakan persamaan (2). 


\section{Evaluasi Model}

Evaluasi dari kinerja model clustering terdiri atas 2 bagian yaitu evaluasi nilai quantization error, didefinisikan pada Persamaan 9 dan evaluasi pada banyaknya data uji yang diprediksi secara benar atau salah oleh model, dihitung menggunakan akurasi yang didefinisikan pada Persamaan 10.

$$
J_{e}=\frac{\left.\sum_{j=1}^{N_{e}}\left\lfloor\sum_{\forall z_{p} \in C_{i j}} d\left(z_{p}, m_{j}\right) /\left|C_{i j}\right|\right\rceil\right]}{N_{c}}
$$

dengan $d\left(z_{p}, m_{j}\right)$ adalah jumlah vektor data yang masuk pada cluster $C_{i j}$ dan $N_{c}$ adalah jumlah cluster yang ditentukan.

$$
\text { akurasi }=\frac{\text { banyaknya prediksi data uji yang benar }}{\text { total data uji }} \times 100 \%
$$

\section{HASIL DAN PEMBAHASAN}

\section{Praproses}

Praproses data bertujuan untuk mengurangi waktu pemrosesan data (running time), seperti ditunjukkan pada Gambar 3.

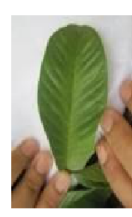

Citra asli

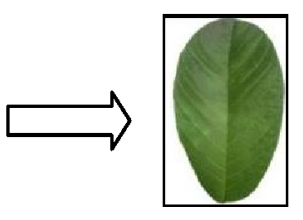

White background
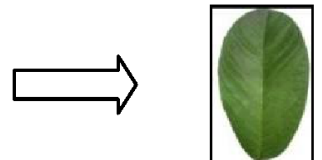

Ukuran citra diperkecil Psidium guajava $L$.

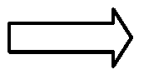

Grayscale

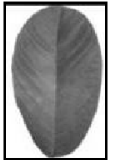

Gambar 3 Hasil praproses citra tumbuhan obat

\section{Ekstraksi Fitur FLBP}

Citra hasil praproses diekstrak menggunakan nilai threshold FLBP fuzzifikasi $(F)$ yaitu 4 dengan operator LBP (8.2). Panjang bin yang dihasilkan pada histogram $F L B P_{P . R}$ bergantung pada jumlah sampling points $(P)$ yang digunakan, yaitu $2^{\mathrm{P}}$. Jumlah $P$ yang digunakan adalah 8 sehingga jumlah bin pada histogram $F L B P_{P_{,} R}$ sebanyak $2^{8}=256 \mathrm{bin}$.

\section{Hasil Percobaan}

Pada tahap ini, metode $k$-means clustering tanpa optimasi dibandingkan dengan yang menggunakan metode optimasi PSO. Metode PSO based $k$-means clustering menggunakan parameter learning rate $c_{1}=1.49$ dan $c_{2}=1.49$, nilai $r_{1}=0.5$ dan $r_{2}=0.5$, untuk bobot inertia $(w)=0.72$ dengan kecepatan maksimum $\left(V_{\max }\right)=2$. Kualitas clustering untuk kedua metode diukur dengan nilai quantization error seperti ditunjukkan pada Tabel 1. Nilai rata-rata quantization error untuk $k$-means clustering adalah sebesar 10072.33, sedangkan untuk PSO based $k$-means clustering sebesar 8146.35. Pada percobaan tersebut, terlihat bahwa metode PSO based k-means clustering lebih baik dalam proses pengelompokan data citra daun tumbuhan obat karena mempunyai nilai quantization error yang lebih kecil. 
Tabel 1 Perbandingan nilai quantization error

\begin{tabular}{ccrr}
\hline No & Citra & K-means & PSO based k-means \\
\hline 1 & Pandan Wangi & 4339.65 & 4934.39 \\
2 & Jarak Pagar & 19661.80 & 13904.40 \\
3 & Dandang Gendis & 4364.76 & 5156.08 \\
4 & Lavender & 3806.62 & 5057.63 \\
5 & Akar Kuning & 14374.70 & 10722.80 \\
6 & Daruju & 10170.90 & 8143.24 \\
7 & Pegagan & 8871.66 & 8776.05 \\
8 & Andong & 5513.26 & 5174.42 \\
9 & Kemangi & 9059.36 & 5804.22 \\
10 & Iler & 9855.74 & 8718.72 \\
11 & Jeruk Nipis & 8866.15 & 8258.82 \\
12 & Bidani & 9634.54 & 7193.98 \\
13 & Gadung Cina & 11800.00 & 8913.41 \\
14 & Tabat Barito & 12499.10 & 9663.39 \\
15 & Nandang gendis kuning & 8135.32 & 6719.57 \\
16 & Bunga Telang & 10304.60 & 7884.19 \\
17 & Mangkokan & 16577.40 & 12204.10 \\
18 & Som Jawa & 6462.30 & 6337.01 \\
19 & Pungpulutan & 14130.30 & 9997.45 \\
20 & Sosor Bebek & 5871.55 & 5672.69 \\
21 & Nanas kerang & 6096.82 & 5725.27 \\
22 & Seligi & 11042.10 & 9305.69 \\
23 & Remak Daging & 18189.00 & 13418.00 \\
24 & Kumis Kucing & 10905.30 & 8144.93 \\
25 & Kemuning & 12039.00 & 7394.52 \\
26 & Cincau Hitam & 23126.20 & 16019.40 \\
27 & Sambang Darah & 6431.79 & 5793.87 \\
28 & Landik & 4226.14 & 5464.62 \\
29 & Jambu Biji & 8910.59 & 7537.37 \\
30 & Handeuleum & 6903.18 & 6350.29 \\
\hline & Total (rata-rata) & 10072.33 & 8146.35 \\
\hline & & &
\end{tabular}

Perhitungan akurasi clustering menunjukkan bahwa jumlah citra yang berhasil diidentifikasi dengan $k$-means clustering adalah sebanyak 95 citra, sedangkan yang berhasil diidentifikasi dengan PSO based k-means clustering adalah sebanyak 142 citra, dengan akurasi sebagai berikut:

$$
\begin{gathered}
\text { Kmeans clustering }=\frac{95}{300} \times 100 \%=31.67 \% \\
\text { PSO based kmeans clustering }=\frac{142}{300} \times 100 \%=47.33 \%
\end{gathered}
$$

Perbandingan akurasi hasil clustering untuk masing-masing spesies citra ditunjukkan pada Gambar 4. Metode k-means clustering menunjukkan bahwa terdapat 27 spesies citra yang dapat diidentifikasi dan 3 spesies yang tidak dapat diidentifikasi. Spesies 9 (Kemangi) memiliki tingkat akurasi 100\%, sedangkan spesies 12 (Bidani), 25 (Kemuning) dan 27 (Sambang Darah) tidak teridentifikasi sehingga nilai akurasinya 0\%. Pada metode PSO based $k$-means clustering, terdapat 28 spesies yang teridentifikasi dengan baik dan 2 spesies yang tidak teridentifikasi. Spesies 2 (Jarak Pagar) dan Spesies 26 (Cincau Hitam) merupakan spesies yang berhasil diidentifikasi dengan tingkat akurasi $100 \%$, sedangkan spesies 12 (Bidani) dan spesies 14 (Tabat Barito) tidak dapat teridentifikasi dan menghasilkan akurasi $0 \%$. 


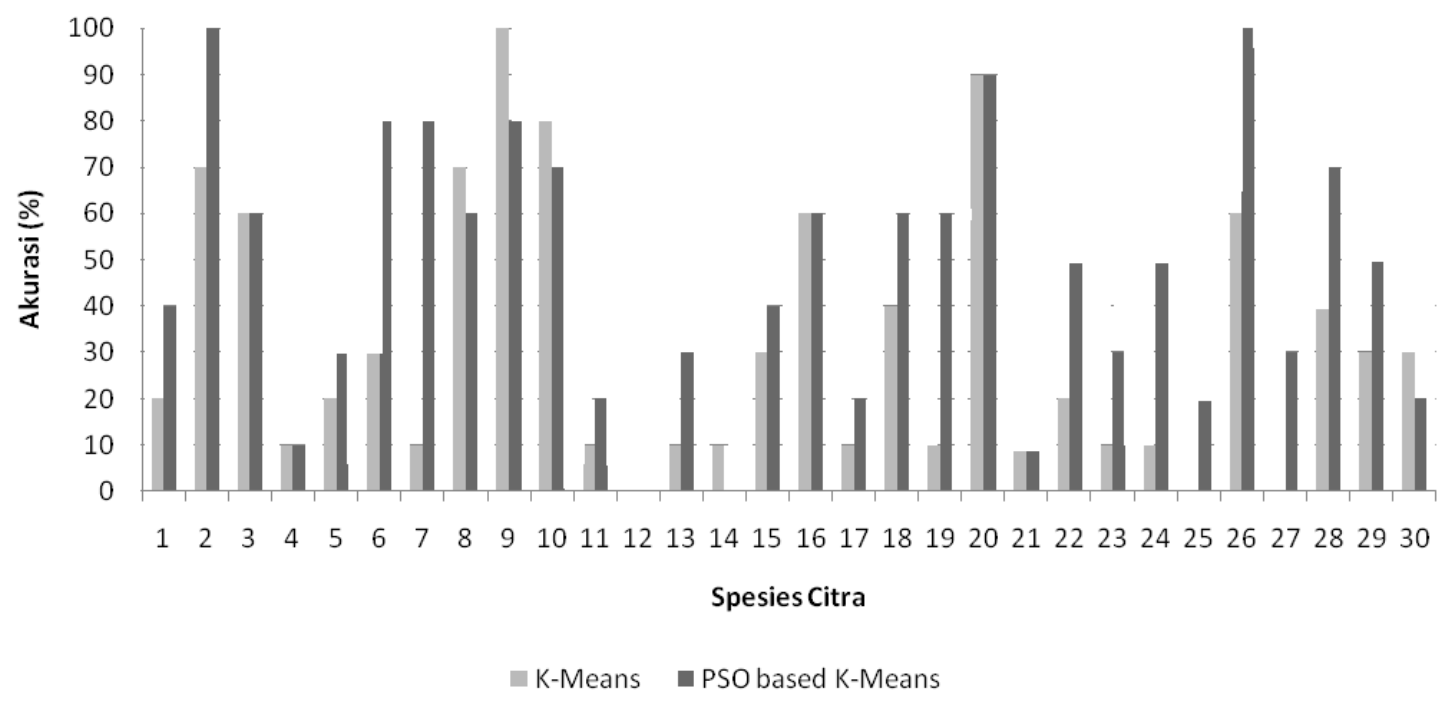

Gambar 4 Grafik perbandingan akurasi per spesies citra

Dari nilai akurasi yang diperoleh, yaitu $31.67 \%$ untuk k-means clustering dan $47.33 \%$ untuk PSO based k-means clustering, dapat disimpulkan bahwa metode PSO based k-means clustering lebih baik daripada metode $k$-means clustering. Kesalahan identifikasi disebabkan oleh tingkat kemiripan citra daun tumbuhan obat yang tinggi karena tekstur daun yang hampir sama. Kemiripan ini membuat akurasi identifikasi menjadi rendah, karena banyak citra yang teridentifikasi sebagai spesies yang berbeda.

\section{SIMPULAN}

Optimasi $k$-means clustering menggunakan metode PSO pada citra tumbuhan obat berhasil diimplementasikan. Metode ini menggunakan data masukan hasil ekstraksi fitur FLBP berupa vektor ciri dari citra daun tumbuhan obat.

Metode PSO based k-means clustering lebih baik daripada metode $k$-means clustering karena memiliki nilai quantization error yang lebih kecil. Nilai quantization error untuk metode PSO based k-means clustering adalah sebesar 8146.35, sedangkan untuk metode $k$ means clustering adalah sebesar 10 072.33. Kesimpulan ini didukung dengan hasil akurasi yang diperoleh, yaitu $47.33 \%$ untuk PSO based k-means clustering dan $31.67 \%$ untuk $k$ means clustering.

\section{DAFTAR PUSTAKA}

Ahonen T, Hadid A, Pietikainen M. 2004. Face recognition with local binary pattern. Springer Verlag Berlin Heidelberg, ECCV, LNCS 3021, hlm 469-481.

Groombridge B, Jenkins MD. 2002. World Atlas of Biodiversity. Earth's Living Resources in the $21^{\text {st }}$ Century, UNEP-WCMC, Cambridge, 0-520-23668-8.

Herdiyeni Y, Wahyuni NKS. 2012. Mobile application for Indonesian medicinal plants identification using fuzzy local binary pattern and fuzzy color histogram. Di dalam: International Conference on Advanced Computer Science and Information System. hlm $1-31$.

Iakovidis DK, Eystratios G, Keramidas EG, Maroulis D. 2008. Fuzzy local binary patterns for ultrasound texture characterization, ICIAR, LNCS 5112, pp. 750-759.

Jain AK, Murty MN, Flynn PJ. 1999. Data clustering: a review. ACM Computing Surveys. 31(3):265-323. 
Kennedy J, Ebenhart R. 1995. A new optimizer using particle swarm theory. Di dalam: Sixth International Symposium on Micro Machine and Human Science. IEEE. 0-7803-2676-8. hlm 39-43.

MacQueen JB. 1967. Some Methods for Classification and Analysis of Multivariate Observations. Western Management Science Institute by office of Naval Research under contract No 233(75), Task No. 047-041, hlm 281-297.

Panchal VK, Kundra H, Kaur J. 2009. Comparative study of particle swarm optimization based unsupervised clustering techniques. International Jurnal of Computer Science and Network Security. 9(10):132-140.

Santosa B, Willy P. 2011. Metoda Metaheuristik Konsep dan Implementasi. Ed ke-1. Surabaya (ID): Guna Widya.

Van der Merwe DW, Engelbrecht AP. 2003. Data Clustering using Particle Swarm Optimization, University of Pretoria, IEEE 0-7803-7804-0/03/\$17.00, hlm 215-220. 